\title{
Factors Influencing Imazapyr Herbicide Removal from Wastewater Using Photocatalytic Ozonation
}

\author{
Salma Bougarrani, ${ }^{1,{ }^{*}}$ Laila El Azzouzi, ${ }^{1}$ Soukaina Akel, ${ }^{1}$ Lahbib Latrach, ${ }^{2}$ \\ Asmae Bouziani ${ }^{1}$ and Mohammed El Azzouzi ${ }^{1}$ \\ ${ }^{1}$ Laboratory of Spectroscopy, Molecular Modeling, Materials, Nanomaterials, Water and Environment, (LS3MN2E) Faculty \\ of Sciences, University Mohammed V. BP 1014, Rabat, Morocco. \\ ${ }_{2}^{2}$ Faculty of Sciences Semlalia, Cadi Ayyad University, PO Box: 2390, Marrakech, Morocco. \\ * Corresponding author: E-mail: salma.bougarrani@gmail.com \\ Tel: +212 660425050, Fax: + 3535698213
}

Received: 28-02-2018

\begin{abstract}
This study investigates the degradation of imazapyr herbicide from wastewater by photocatalytic ozonation using $\mathrm{TiO}_{2}$ as a semiconductor. Effects of operational parameters on imazapyr removal efficiency including $\mathrm{TiO}_{2}$ dosing, initial herbicide concentration and $\mathrm{pH}$ were also studied. Obtained results showed that more than $90 \%$ of removal efficiency representing the disappearance of imazapyr was maintained until $7 \mu \mathrm{M}$ in the presence of $200 \mathrm{mgL}^{-1}$ of $\mathrm{UV} 100-\mathrm{TiO}_{2}$. Otherwise, the degradation of imazapyr followed the first-order kinetics with a photocatalytic rate constant of $0.247 \mathrm{~min}^{-1}$, and complete degradation was achieved within 20 min using photocatalytic ozonation for $5 \mu \mathrm{M}$ of Imazapyr at $\mathrm{pH} 7$.
\end{abstract}

Keywords: Degradation; Imazapyr herbicide; Ozonation; Photocatalytic Ozonation; Wastewater treatment

\section{Introduction}

Persistent organic pollutants such as pesticides have attracted global environmental concerns in recent decades due to its adverse impacts on the environment and public health. Among the various pesticides, imazapyr is one of the most widespread types of contaminants of waters and soils, often found in the municipal sewage effluents and soil with varying trace concentrations in different parts of the world. ${ }^{1-2}$

Imazapyr, 2-(4-methyl-5-oxo-4-propan-2-yl-1Himidazol-2-yl) pyridine-3-carboxylic acid, being a hetero aromatic molecule, ${ }^{3}$ is a non-selective herbicide which belongs to the imadazolinone family. Imazapyr is a persistent herbicide, with a half-life varying from 21 days to 49 months, and a high mobility in soils. ${ }^{3-4}$ Therefore, it is likely suspected to contaminate groundwater. ${ }^{5}$ Elimination of imazapyr present in drinking water by treatment with ozone has been demonstrated to be unsuccessful since half of the initial compound remains in water after the process. The photocatalytic oxidation of imazapyr has been studied previously using commercial $\mathrm{TiO}_{2}$ as well as newly synthesized mesoporous $\mathrm{TiO}_{2}$ materials. ${ }^{6}$ However, more studies are still needed to better understand the effect of the oxidative approaches on the control of this herbicide.
In recent years, various technologies have been developed and tested in laboratory scales or pilot plants to remove various recalcitrant organic pollutants from wastewater in order to minimize the potential health risks associated with exposure to these chemical pollutants. ${ }^{4}$ One of the alternatives to gain greater mineralization efficiency is the use of ozone in the presence of catalyst in order to enhance the free hydroxyl radicals production. ${ }^{4-5}$ The photocatalytic ozonation have been studied by many studies worldwide and the high efficiency of this treatment has been explained by a synergistic effect between ozonation and photocatalysis. The photogenerated electrons can react with ozone molecules generating ozonide radicals while decreasing the possible recombination of electronehole pairs. Pizarro et al. ${ }^{5}$ and Ibrahimi et al., ${ }^{6}$ reported that among six different advanced oxidation processes, photocatalytic ozonation was the most efficient for completing mineralisation of 4- chloronitrobenzene. These promising techniques are used for the treatment of contaminated water and wastewater to evaluate their capability in the decomposition of pollutants such as pesticides and to assess the treatment efficiencies of these combinations. ${ }^{7}$ 
The advanced oxidation processes (AOPs) have been developed as one of the most promising options in the removal of various persistent organic pollutants by the generation of hydroxyl radicals $(\mathrm{OH}) \cdot{ }^{8-9}$ Due to its low-cost and chemical stability, semi-conductor material like $\mathrm{TiO}_{2}$ has been successfully used in recent years. ${ }^{10-12}$ However, The degradation of Imazapyr has also been investigated by other authors using photocatalysis and ozone and results showed lower concentration compared to photocatalytic ozonation. ${ }^{13-30}$ The photocatalytic ozonation degradation of pesticides is largely dependent on operating parameters such as $\mathrm{TiO}_{2}$ dosage, initial herbicide concentration and solution $\mathrm{pH}^{31-32}$ Understanding the effects of these factors on the photocatalytic degradation efficiency have an importance when designing a sustainable and efficient technique for wastewater treatment.

Based on this background informations, the present study aimed at performing a comprehensive evaluation of the capacity of photocatalytic ozonation to remove imazapyr from wastewater.

The laboratory studies reported in this paper investigates the capacity and the applicability of $\mathrm{TiO}_{2}$-photocatalytic ozonation in removing imazapyr herbicide from wastewater. Operational parameters such as $\mathrm{TiO}_{2}$ initial concentration, initial herbicide concentration and $\mathrm{pH}$ were also investigated.

\section{Material and Methods}

Imazapyr herbicide, (95\%) was purchased from American Cyanamid Company. $\mathrm{TiO}_{2}$ Hombikat UV100 (99\%) was purchased from Sachtleben Chemie in powdered form. The chemical structure of imazapyr herbicide is shown in figure 1. Potassium indigo trisulfonate was purchased from Riedel-de Hahn AG. The other chemicals used in the experiments were purchased from Riedel-de Hahn AG. They were all of analytical grade and used without further purification. All solutions were prepared using Milli-Q water at room temperature collected from Milli-Q apparatus (Millipore, Bedford).

Sample analysis from the study of the photocatalytic degradation of imazapyr was carried out using a mass spec-

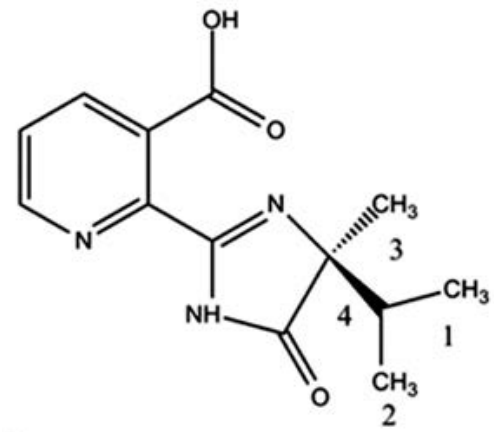

Figure 1: Chemical structure of imazapyr herbicide. trometry coupled to electrospray ionization system (ESI) for a qualitative and quantitative analysis. MS analysis was performed on Bruker Esquire 3000 plus mass spectrometer equipped with an ESI interface and an ion trap (Bruker-Daltonics Analytik GmbH Bremen, Germany). The ESI probe tip and capillary potentials were set at $2.5 \mathrm{kV}$ and 25 $\mathrm{V}$, respectively. The concentration of aqueous ozone was determined by Spectrometric method indigo trisulfonate according to Sanchez et al.,$^{13}$ and mouradi et al. ${ }^{17}$ The absorption analysis of the indigo was monitored by Shimadzu UV-160A UV-Vis Spectrophotometer at $600 \mathrm{~nm}$.

Titanium dioxide $(100 \%$ anatase, average particle size of $10 \mathrm{~nm}$ and BET Method-Brunauer, Emmett and Teller [BET] surface of $>250 \mathrm{~m}^{2} \mathrm{~g}^{-1}$ ) was used without any pre-treatment.

In a typical reaction, $200 \mathrm{mg} / \mathrm{L}$ of $\mathrm{TiO}_{2}$ were added to $500 \mathrm{~mL}$ of $5 \mu \mathrm{M}$ of imazapyr solution in a double walled cylindrical photoreactor (figure 2). Then, the solution was exposed to ultrasonic treatment for 2 minute in order to suspend the catalyst. Immediately afterwards, the stirring was started and maintained over $1 \mathrm{~h}$ in the dark to ensure the adsorption equilibrium between the solution and the catalyst particles. The imazapyr degradation experiments were carried out in a simple photocatalyzed ozonation reactor, as presented in figure 2 , with combining photocatalysis and ozonation.

The irradiation experiments were carried out under light generated by a medium pressure mercury lamp at 150W in a Duran cell $(\lambda>300 \mathrm{~nm})$, placed inside the reactor. A cooling water system was set up to prevent overheating of the lamp and of the solution. Samples were taken every $10 \mathrm{~min}$ and filtered two times in order to remove all the catalyst. The photocatalytic ozonation degradation of Imazapyr herbicide was investigated in an aqueous suspension 1: 3 acetone/water mixture in the presence of pure titanium used as a catalyst. Imazapyr showed important

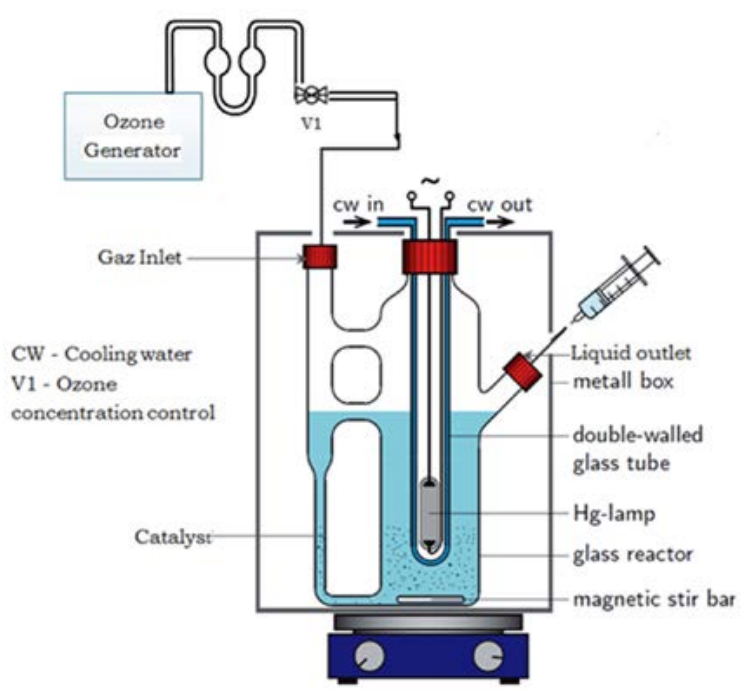

Figure 2: Scheme of photocatalytic ozonation reactor used for imazapyr degradation. 
fragments molecular ion peak at $\mathrm{m} / \mathrm{z}=262$ and $\mathrm{m} / \mathrm{z}=284$, The MS-ESI detects the Imazapyr under two forms (combinated to $\mathrm{H}^{+}$wich gives $\mathrm{m} / \mathrm{z}=262$ and combinated to $\mathrm{Na}^{+}$ with $\mathrm{m} / \mathrm{z} 284$ ) and their degradation was followed as a function of time.

\section{Results and Discussion}

\section{1. Effect of $\mathrm{TiO}_{2}$ Dose on Imazapyr Degradation}

Variations of Imazapyr removal rate under different $\mathrm{TiO}_{2}$ dose are presented in figure3. Imazapyr degradation increased slowly and reached the maximum removal rate of $93.0 \%$ in the concentration of $200 \mathrm{mg} / \mathrm{L}$. Thus, this $\mathrm{TiO}_{2}$ dose $(200 \mathrm{mg} / \mathrm{L})$ could be considered as the optimal concentration of hombikat UV 100. The optimal amount of Hombikat UV 100 agrees well with reported results by other authors. ${ }^{14-26}$ This improvement can be attributed to the increasing of active sites by providing more $\mathrm{TiO}_{2}$ particles, which plays the semiconductor role in the photocatalysis process. Consequently, the formation of electron-hole pairs and reactive hydroxyl radicals on the surface of semiconductor increased, which improved the oxidation of imazapyr into other intermediates. ${ }^{15-27}$

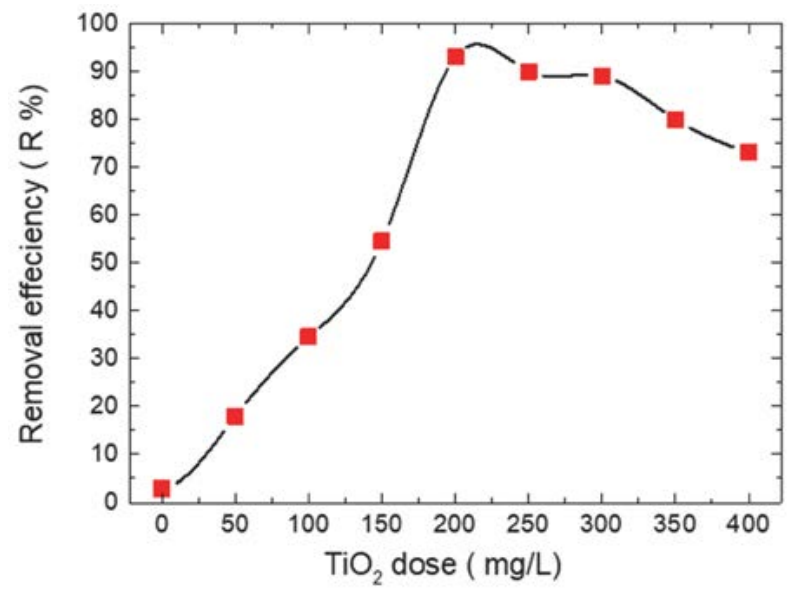

Figure 3: Removal rate of imazapyr under variation of $\mathrm{TiO}_{2}$ concentration. C(Imazapyr $)=5 \mu \mathrm{M}$; stirring speed $=1000 \mathrm{~min}^{-1}$, aqueous suspension $1: 3$ acetone/ Milli-Q water.

\section{2. Effect of Initial Herbicide Concentration}

The pollutant concentration in water is an important factor to determine the oxidation efficiency and the synergistic effects of photocatalytic ozonation processes. ${ }^{12-15}$ The effect of the initial herbicide concentration was studied for six concentrations of imazapyr by photocatalytic ozonation. The initial herbicide concentrations were $1 \mu \mathrm{M}$, $3 \mu \mathrm{M}, 5 \mu \mathrm{M}, 7 \mu \mathrm{M}, 9 \mu \mathrm{M}$ and $15 \mu \mathrm{M}(0.26 \mathrm{mg} / \mathrm{L}, 0.79 \mathrm{mg} / \mathrm{L}$, $1.31 \mathrm{mg} / \mathrm{L}, 1.83 \mathrm{mg} / \mathrm{L}, 2.36 \mathrm{mg} / \mathrm{L}, 3.9 \mathrm{mg} / \mathrm{L}$ respectively).
For this series of experiments the catalyst and the ozone doses were kept constant at $200 \mathrm{mg} / \mathrm{L}$ and $10 \mathrm{mg} / \mathrm{L}$ respectively. The irradiation time was fixed at $10 \mathrm{~min}$ for all samples after the adsorption step under dark conditions.

Obtained results showed that more than $90 \%$ of removal efficiency representing the disappearance of imazapyr was maintained until $7 \mu \mathrm{M}$, further increase of imazapyr concentration leads to decrease in removal efficiency (figure 4). A possible explanation resides in the fact that as imazapyr concentration rises, it is possible that more organic substances are deposed on the surface of $\mathrm{TiO}_{2}$, whereas less number of photons are available to reach the catalyst surface and the probability of reaction between imazapyr molecules and oxidizing species also decreases, thus resulting in less degradation percentage. ${ }^{18-32}$

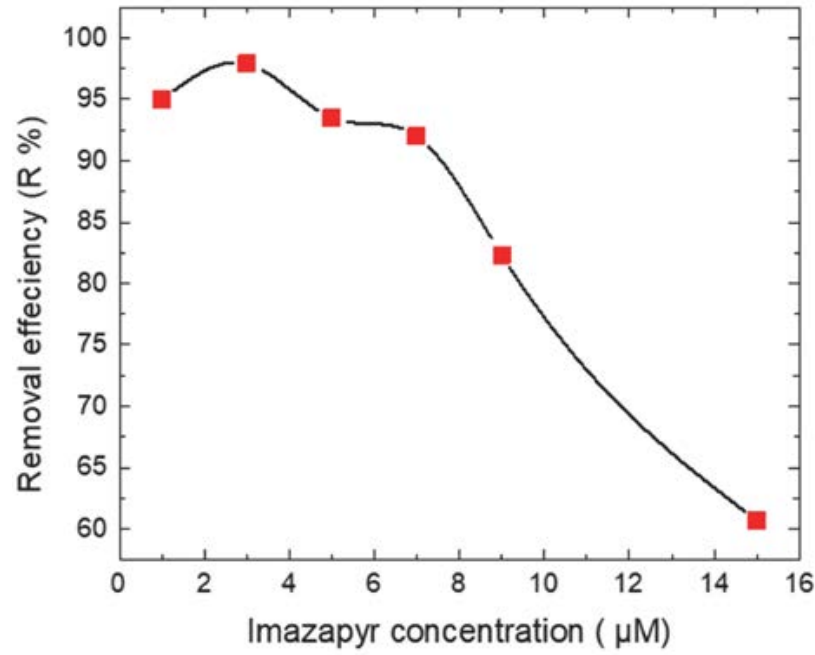

Figure 4: Removal efficiency of imazapyr as a function of imazapyr concentration, mcatalyst $=100 \mathrm{mg}$; stirring speed $=1000 \mathrm{~min}^{-1}$, aqueous suspension 1:3 acetone/ Milli-Q water.

\section{3. Effect of pH Influence on Imazapyr Degradation}

Knowledge of the kinetics required to assess the efficiency of systems engineered for the oxidation of a variety of pollutants. Reliable kinetic studies require obvious substrate decay measurements. Thus, for comparison of the efficiency of these treatment processes, kinetic studies of imazapyr decomposition were carried out.

In all experimental runs, imazapyr concentration was found to decrease with irradiation time. A first order kinetics fitting of the thus obtained concentration vs. time plots allows to calculate the respective first order rate constants. Based on the exponential decay of concentration of imazapyr, the photoactivity profile was fitted assuming a first order reaction.

$$
C=C_{0} \exp (-k \cdot t)
$$


In which $\mathrm{C}$ is the concentration of imazapyr at time $\mathrm{t}$, Co is the initial concentration, and $\mathrm{k}$ is the observed rate constant.

Many authors have reported that the kinetic behavior of photocatalytic reaction can be described by a modified Langmuir-Hinshelwood model, Atitar et al., ${ }^{18}$ and Djerdj et al. ${ }^{19}$

The influence of $\mathrm{pH}$ on the effectiveness of imazapyr degradation by photocatalytic ozonation is shown in figure 5. The degradation experiments were carried out at $\mathrm{pH}$ values of 3,7 , and 10. Imazapyr removal rate reached a maximum at $\mathrm{pH} 7$ with a first order rate constant of 0.247 $\mathrm{min}^{-1}$. However, for $\mathrm{pH} 3$ and 10 , the photocatalytic activity decreased appreciably. The rates constant at $\mathrm{pH} 3$ and pH 10 are $0.107 \mathrm{~min}^{-1}, 0.134 \mathrm{~min}^{-1}$ respectively (Table1). The study of $\mathrm{pH}$ influence on the photocatalytic ozonation process would be helpful to understand its underlying mechanism and would help obtaining a higher degree of removal. Based on the exponential decay of imazapyr concentration, the degradation by photocatalytic ozonation profile was fitted assuming a first order reaction model. Similar finding have been reported by Usharani et al., ${ }^{14}$ and by Gar Alalma et al. ${ }^{15}$ These authors have reported first order reaction kinetics for the degradation and mineralization of chlorinated pesticides and insecticides and other various water pollutants by photocatalytic ozonation. ${ }^{14-33}$

The results, shown in figure 5, demonstrates that the optimal conditions for imazapyr degradation with photocatalytic ozonation is neutral $\mathrm{pH}$. On the other hand, the combination of two oxidation systems, ozonation and photocatalysis, for water treatment under optimal conditions are reported to have increased oxidation efficiencies (synergy) compared to the sum oxidation efficiencies of these two oxidation systems separately. ${ }^{32-36}$ Several studies have discussed the synergistic effects of photocatalytic ozonation on degradation and removal of different substances from aqueous solutions and the effects are reported in terms of the degradation and/or mineralization effi-

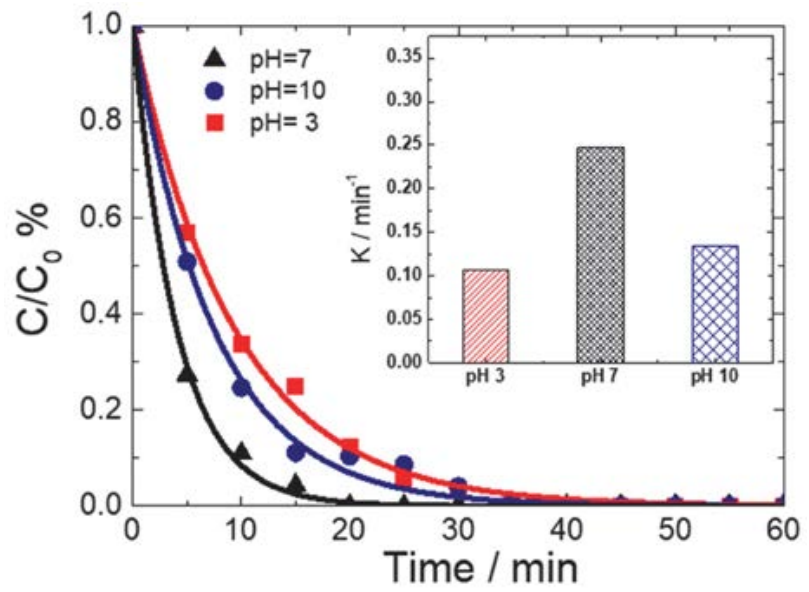

Figure 5: Concentration of imazapyr as a function of time for different $\mathrm{pH}, \mathrm{C}($ Imazapyr $)=5 \mu \mathrm{M})$; stirring speed $=1000 \mathrm{~min}^{-1}, \mathrm{~m} \mathrm{TiO}_{2}$ $=100 \mathrm{mg}$ ). aqueous suspension $1: 3$ acetone/ Milli- $\mathrm{Q}$ water. ciencies or oxidation rate constants of model water pollutants. ${ }^{17-27}$ The efficiency of photocatalytic ozonation is mainly attributed to the formation of more reactive and non-selective hydroxyl radicals in the oxidation medium, which react with almost all organic molecules at a rate of $10^{6}-10^{9} \mathrm{M}^{-1} \mathrm{~s}^{-1} \cdot{ }^{18-25-37}$ The photogenerated electrons can react with ozone molecules generating ozonize radicals while decreasing the possible recombination of electron hole pair, so better electron- whole separation. In addition to the synergistic effects which occur during photocatalytic ozonation compared to simple photocatalysis in presence of oxygen. Bougarrani et al., ${ }^{36}$ and Wang et al., ${ }^{24}$ also reported similar results for the mineralization of aniline, dibutyl phthalate, respectively.

Table 1: Rate constant of imazapyr degradation with photocatalytic ozonation for different $\mathrm{pH}$.

\begin{tabular}{rccc}
\hline pH & \multicolumn{2}{c}{ Photocatalytic ozonation } & \\
& Rate constant K & $\mathbf{R}^{\mathbf{2}}$ & Standard Deviation \\
\hline 3 & $0.107\left(\mathrm{~min}^{-1}\right)$ & 0.997 & 0.0012 \\
7 & $0.247\left(\mathrm{~min}^{-1}\right)$ & 0.997 & 0.0009 \\
10 & $0.134\left(\mathrm{~min}^{-1}\right)$ & 0.995 & 0.0015 \\
\hline
\end{tabular}

\section{Conclusions}

This study demonstrated the ability of photocatalytic ozonation using $\mathrm{TiO}_{2}$ as semiconductors for the degradation of imazapyr herbicide as organic pollutants. Imazapyr degradation is strongly influenced by the operating parameters such as $\mathrm{TiO}_{2}$ concentration, initial imazapyr concentration and $\mathrm{pH}$. Under optimized conditions $\left(\mathrm{TiO}_{2}\right.$ dose of $200 \mathrm{mg} / \mathrm{L}, 5 \mu \mathrm{M}$ of initial imazapyr concentration and $\mathrm{pH}$ 7), up to $95 \%$ of imazapyr removal was achieved within 20 min with removal rate constant of $0.247 \mathrm{~min}^{-1}$. Results of the present investigation suggest that photocatalytic ozonation using $\mathrm{TiO}_{2}$ is efficient for the removal of imazapyr form wastewater. The high efficiency of photocatalytic ozonation could be explained by a synergistic effect between ozonation and photocatalysis. The photogenerated electrons can react with ozone molecules generating ozonize radicals while decreasing the possible recombination of electron hole pair, so better electron- whole separation.

Therefore, the application of photocatalytic ozonation under the optimal conditions is recommended for organic pollutants treatment such as imazapyr herbicides in order to promote environmental and human health protection.

\section{References}

1. Assalin M. R., De Moraes S. G., Queiroz C. N., Ferracini V. L. \& Duran N., J Environ Sci Health B, 2009, 45,1, 89-94.

DOI:10.1080/03601230903404598 
2. Antoniou M. G., Zhao C., O'Shea K. E., Zhang G., Dionysiou D., Han C., Nadagouda M. N., Choi H., Fotiou T., Triantis T. M. \& Hiskia. RSC $a d v$. 2016, 1-34.

3. Atitar M. F., Dillert R. \& Bahnemann D. W. J. Phys. Chem. C. 2017, 121 (8), 1-36. DOI:10.1021/acs.jpcc.6b11673

4. Oller I., Gernjak W., Maldonado M. I., Perez-Estrada L. A., Sanchez-Perez J. A., Malato S., J Hazard Mater B, 2006, 138, 507-517. DOI:10.1016/j.jhazmat.2006.05.075

5. Pizarro P., Guillard C., Perol N., Herrmann J.-M., Catal. Today, 2005, 101, 211-218. DOI:10.1016/j.cattod.2005.03.008

6. Ebrahimi H., Ghorbani Shahna F., Arch Environ Prot, 2017, 43, 65-72. DOI:10.1515/aep-2017-0006

7. Bamba D., Atheba P., Robert D., Trokourey A., Dongui B., Environ. Chem. Lett. 2008, 6, 163-167.

DOI:10.1007/s10311-007-0118-x

8. Boggard O. K., Gimsing A. L, Pest Manag Sci. 2008, 64, 441456. DOI:10.1002/ps.1512

9. Shifu C., Yunzhang L., Chemosphere, 2007, 67, 1010-1017. DOI:10.1016/j.chemosphere.2006.10.054

10. Okehata K., EI-Din M. G., Ozone Sci. Eng., 2005, 27, 83.

11. Maddila S., Rana S., Pagadala R. \& Jonnalagadda S. B., Desalin Water Treat, 2015, 1-15.

12. Maddila S., Ndabankulu V. O., Jonnalagadda S. B., Global Nest J. 2016, 18(2), 269-278.

13. Sanchez L., Peral J., \& Domenech X., Appl Catal B, 1998, 19, 1, pp. 59-65. DOI:10.1016/S0926-3373(98)00058-7

14. Usharani, Muthukumar M., and Kadirvelu K., Int. J. Environ. Res. 2012, 6(2), 557-564.

15. Gar Alalma M., Tawfika A., Ookawara S., J. wat Proc Eng. 2015, 8, 55-63.

16. Hameed B. H., Akpan U. G., J Hazard Mater. 2009, 170, 520529. DOI:10.1016/j.jhazmat.2009.05.039

17. Mouradi, M., Bouizgaren, A., Farissi, M. and Ghoulam, C., Irrigation and Drainage 2017,

18. Atitar M. F, and Bahnemann D. W., J. Phys. Chem. C, 2017, $1-36$.

19. Djerdj I., Arcon D., Jagliid Z., Niederberger M. J. Solid State Chem. 2008, 181, 1571- 1581.

DOI:10.1016/j.jssc.2008.04.016

20. Lissemore L., Hao C.Y., Yang P., Sibley P. K, Mabury S., and Solomon K. R. J. Chemosphere, 2006, 64, 717-729.

DOI:10.1016/j.chemosphere.2005.11.015
21. Sato, K., Iwashima, N., Wakatsuki, T. and Masunaga, T., J. Soil Sci. Plant Nutr., 2011, 57(4), pp.607-618.

DOI:10.1080/00380768.2011.594966

22. Bargaz, A., Isaac, M. E., Jensen, E. S. and Carlsson, G., J. Soil Sci. Plant Nutr., 2016, 179 (4), 537-546.

23. Armaković S. J., Armaković S., Finčur N. L., Šibul F., Vione D., Šetrajčić J. P. \& Abramović B. F. RSC Advances, 2015, 5 (67), 54589-54604. DOI:10.1039/C5RA10523D

24. Wang R. M., Liu C. M, Zhang H. Z., Chen C. P., Guo L., Xu H. B., Yang S. H. Appl. Phys. Lett. 2004, 85, 2080-2082. DOI:10.1063/1.1789577

25. Putra E. K., Pranowo R., Sunarso J., Indraswati N., Ismadji S. Water Res, 2009, 43, 2419-2430.

DOI:10.1016/j.watres.2009.02.039

26. Klavarioti, M., Mantzavinos, D., Kassinos, D. Environ. Int. 2009, 35, 402-417. DOI:10.1016/j.envint.2008.07.009

27. Kümmerer, K. J. Environ. Manage, 2009, 90, 2354-23. DOI:10.1016/j.jenvman.2009.01.023

28. Zhang G., Wang Q., Zhang W., Yuan T. and Wang P. Photochem Photobiol Sci, 2017, 98-103.

29. Safari G. H., Hoseini M., Seyedsalehi M., Kamani H., Jaafari J., Mahv A. H. Int. J. Environ. Sci. Technol. 2015, 12 603-616. DOI:10.1007/s13762-014-0706-9

30. Bourgin M., Borowska E., Helbing J., Hollender J., Kaiser H. P., Kienle C., McArdell C. S., Simon E. \& Gunten U. Water Res. 2017, 122, 234-245. DOI:10.1016/j.watres.2017.05.018

31. Ebrahimi H., Shahna F. G., Bahrami A., Jaleh B. \& Abed K. A. Arch Environ prot. 2017, 43 (1), 65-72.

DOI:10.1515/aep-2017-0006

32. Bougarrani S., El azzouzi L., Bouziani A., Akel S., Latrach L., Baicha Z., El azzouzi M. Mor. J. Chem.2017, 5 (3), 446-452.

33. Hermosilla D., Merayo N., Gascó A. \& Blanco Á. Environ Sci Pollut Res, 2015, 22 (1), 168-191.

DOI:10.1007/s11356-014-3516-1

34. Iglesias O., Fernández deDios M.A., Tavares T., Sanromán M. A. \& Pazos M. J. Ind. Eng. Chem 2015, 27 (1), 276-282.

DOI:10.1016/j.jiec.2014.12.044

35. Ismail A., Abdelfattah I., Faisal M. \& Hela A. J Hazard Mater. 2018, 342 (15), 519-526. DOI:10.1016/j.jhazmat.2017.08.046

36. Bougarrani S., Skadell K., Arndt R., El Azzouzi M., and Gläser R., J. Environ. Chem. Eng., 2018, 6 (2), 1934-1942.

DOI:10.1016/j.jece.2018.02.026

37. Zhang G., Wang Q., Zhang W., Yuan T. \& Wang P. Photochem Photobiol Sci. 2017, 15 (8), 98-103.

\section{Povzetek}

Študija preučuje razgradnjo herbicida Imazapyr iz odpadnih vod s fotokatalitično ozonacijo katalizirano s $\mathrm{TiO}_{2}$. Preučevali smo vpliv količine dodanega $\mathrm{TiO}_{2}$, koncentracije herbicida in $\mathrm{pH}$ vrednosti. Rezultati so pokazali, da lahko dosežemo 90 \% razgradnjo pri koncentracijah herbicida Imazapyr v koncentracijah do $7 \mu \mathrm{M}$ ob prisotnosti $\mathrm{UV}_{100}-\mathrm{TiO}_{2} \mathrm{v}$ koncentraciji $200 \mathrm{mgL}^{-1}$. Razpad herbicida Imazapyr lahko opišemo s kinetiko prvega reda s konstanto fotolize 0.247 $\mathrm{min}^{-1}$. S fotokatalitično ozonacijo smo dosegli popolno razgradnjo $5 \mu \mathrm{M}$ herbicida Imazapyr pri pH vrednosti $7 \mathrm{v} 20$ $\min$. 